\title{
O INTERSTÍCIO E A INCERTEZA: AS FACES DO FANTÁSTICO EM “O GATO PRETO” DE EDGAR ALLAN POE
}

\section{THE MOMENT BETWEEN AND UNCERTAINTY: THE FACES OF THE FANTASTIC IN “THE BLACK CAT” BY EDGAR ALLAN POE}

\section{Evanir Pavloski* \\ $U E P G$}

Resumo: O objetivo do presente artigo é revisitar o icônico conto "O gato preto", de Edgar Allan Poe, tendo como perspectivas teórico-críticas a valorização da ambiguidade no texto e o seu efeito sobre o leitor. Para tanto, utilizaremos como aporte teórico principal a obra A ameaça do fantástico, de autoria do crítico catalão David Roas, assim como suas referências a conceitos de outros pensadores, a exemplo de Pierre Castex, Louis Vax e Tzvetan Todorov. Pretendemos demonstrar que um processo de desestabilização da visão de mundo do receptor se efetiva tanto na compreensão das atitudes do protagonista como resultantes da influência de forças malignas quanto na análise psicológica e discursiva da personagem. Como mostraremos, em ambos os pontos de vista sobre a face da monstruosidade humana, as representações lógicas e pacificadoras de realidade têm parte de suas enganosas integridades ameaçadas.

Palavras-chave: Fantástico. Desestabilização. Real. Poe. “O gato preto”. David Roas.

Abstract: The aim of this work is to revisit the iconic short story "The Black Cat", written by Edgar Allan Poe, on the theoretical-critical basis of the ambiguity's importance in the text and its effect on the reader. In order to accomplish this objective, we will take as our main theoretical support the work titled The Menace of the Fantastic, written by the Spanish critic David Roas, as well as its references to concepts of other thinkers, such as Pierre Castex, Louis Vax e Tzvetan Todorov. We intend to show that a destabilization process of the reader's worldview takes place both through the understanding of the protagonist's attitudes as results of the influence of evil forces and through the character's psychological and discursive analysis. As we shall reveal, in both views on the face of human monstrosity, the logical and pacifying representations of reality have part of their deceiving integrities put at risk.

Keywords: Fantastic. Destabilization. Real. Poe. “The Black Cat”. David Roas.

\author{
* Doutor em Estudos \\ Literários. E-mail: \\ evanir.pv@gmail.com
}


A proposta de revisitar espaços ficcionais, cujas formalizações literárias já foram inscritas no cânone ocidental, pode representar uma trajetória analítica constantemente ameaçada pelos espectros do anacronismo e de um suposto esgotamento crítico. Entretanto, as transformações histórico-culturais, as renovações dos horizontes de expectativas dos leitores e o reconhecimento de outros roteiros teóricos, tanto para os estudos do que convencionalmente denominamos de realidade quanto para aqueles que se dedicam às suas formas de representação artística, pluralizam os caminhos a serem seguidos, a partir das diferentes encruzilhadas possíveis entre recortes sincrônicos e diacrônicos. Nessa perspectiva, o objeto literário escapa do formalismo que ameaça fossilizar seus sentidos e se integra em um fluxo histórico de leituras e releituras que pode, inclusive, lançar luz sobre os aspectos que constituem o próprio cânone.

Em sua icônica obra A história da literatura como provocação à teoria literária, Hans Robert Jauss afirma que:

A obra literária não é um objeto existente em si mesmo, oferecendo a cada observador, em cada momento, a mesma aparência. Não é um monumento oferecendo, em monólogo, a revelação da sua essência intemporal. É muito mais como uma partitura construída sobre as ressonâncias sempre renovadas das leituras, as quais arrancam o texto da materialidade das palavras e atualizam a sua existência. (JAUSS, 2003, p. 62).

É justamente a esse processo de atualização do texto literário por parte de diferentes públicos leitores que subjaz o surgimento de novos olhares teórico-críticos que, sem desconsiderar o contexto da escritura da obra, suplantam os limites temporais e interpretativos impostos por determinadas correntes exegéticas.

Diante do exposto, o propósito de analisar contemporaneamente um conto de um autor como Edgar Allan Poe (1809-1849) não apenas comprova o potencial de atualização de sua narrativa, mas também permite reflexões sobre elementos do seu plano de expressão e de conteúdo, a partir de áreas de estudos que surgiram posteriormente à sua produção como, por exemplo, a psicanálise e os estudos culturais. Sobre a atemporalidade da obra de Poe, Julio Cortázar salienta que

Há em nós uma presença obscura de Poe, uma latência de Poe. Todos nós, em algum lugar de nossa pessoa, somos ele, e ele foi um dos grandes porta-vozes do homem, aquele que anuncia o seu tempo noite adentro. Por isso sua obra, atingindo dimensões extratemporais, as dimensões da natureza profunda do homem sem disfarces, é tão profundamente temporal a ponto de viver num contínuo presente, tanto nas vitrinas das livrarias como nas imagens dos pesadelos, na maldade humana e também na busca de certos ideais e de certos sonhos. (CORTÁZAR, 2006, p. 104). 
Neste artigo, objetivamos discorrer especificamente sobre a obra “ $\mathrm{O}$ gato preto”, publicada na edição do Saturday Evening Post de 19 de agosto de 1843, tendo como aporte teórico principal o texto A ameaça do fantástico, de autoria de David Roas, e publicado no Brasil em 2014.

Para o autor catalão, o gênero literário em questão é fundamentalmente caracterizado pela desestabilização do senso de realidade do leitor, demonstrando a falácia de qualquer tentativa de determinação absoluta do real. Como veremos, essa definição se revela produtiva para a investigação não apenas das obras de Poe, mas também de seus tributários.

Contudo, antes da apresentação sistemática dos conceitos de Roas e da análise do conto do autor estadunidense à luz de suas proposições, consideramos necessária uma breve apresentação de alguns referenciais teóricos anteriores ao referido texto, que integram uma herança epistemológica com a qual Roas dialoga e que, de certa forma, já apontam para algumas das suas conclusões. Essa aproximação demonstra que, assim como no desenvolvimento dos gêneros ficcionais (o fantástico, inclusive), a teoria evolui com uma face voltada para o passado e outra para o futuro.

Tal imagem ambivalente poderia ser associada à Máscara da Eternidade mostrada por Joseph Campbell na série The Power of Myth transmitida pela PBS (Public Broadcasting Series) em 1988. Esse artefato indiano apresenta em seu centro um rosto em aparente meditação, do lado esquerdo uma fronte masculina e do lado direito um semblante feminino. Campbell se remete a essa escultura para afirmar que ao se afastar do todo transcendental, o pensamento recai na dinâmica do binarismo que organiza a linguagem e, consequentemente, o próprio mundo.

Assumindo como verdadeiro esse pressuposto, a face do centro da máscara corporificaria o espaço transcendente de intermédio entre as oposições que regem a consciência e o imaginário. Esse espaço, portanto, seria o interstício entre duas possibilidades contrárias de concretização de elementos do real. Em certo sentido, seria uma utopia do sentido, desde que nos atenhamos às raízes etimológicas do termo (do grego u-topus: não lugar), ou seja, uma zona de intermitência de significação, a qual não é produzida pelo esvaziamento de quaisquer formas de representação, mas justamente pelo amálgama de perspectivas diferentes de entendimento do mundo.

Em sua tese de doutorado, Karen Pike utiliza a descrição de Campbell como forma de entendimento do próprio gênero fantástico, o qual, segundo ela, seria também uma esfera de suspensão do binarismo sobrenatural/real, uma vez que, ao longo do diálogo do leitor com o texto, as duas visões seriam igualmente possíveis. Para a autora, a irrupção do insólito nas narrativas fantásticas acarreta uma insuficiência da linguagem, que é desafiada pelo indescritível e/ou pelo dúbio. 
Eu defenderei que "o interstício” é a chave para entender a natureza, o modus operandi e mesmo o apelo das narrativas fantásticas. Essas narrativas são exercícios de apreensão de algo além da linguagem, algo inominável ou indescritível que apenas pode emergir quando a linguagem demonstra as suas ineficiências. ${ }^{1}$ (PIKE, 2010, p. 02, tradução nossa).

Essas colocações podem ser vistas como índices remissivos para abordagens teóricas que marcaram o estudo do gênero fantástico no século XX. Pierre George Castex (1947), por exemplo, defende que o elemento definidor do fantástico é uma abrupta invasão de uma sensação de mistério no mundo (supostamente) conhecido pelo leitor. Louis Vax (1965), por sua vez, afirma que a literatura fantástica é marcada primordialmente pela incitação de uma duradoura sensação de incerteza no leitor em relação aos eventos narrados. De acordo com essa caracterização do gênero, o interstício formado pelo texto entre o sobrenatural e o real se mantém mesmo depois do final de leitura, permanência que, como veremos, também é prevista e valorizada pelos fundamentos conceituais de David Roas.

Finalmente, é preciso considerar a influente teoria de Tzvetan Todorov em sua Introdução à literatura fantástica (1970) e sua ênfase na hesitação como característica definidora do efeito fantástico. Indubitavelmente, os postulados do autor búlgaro reconhecem e valorizam a posição do gênero no interstício entre as duas possibilidades citadas, as quais, no caso específico da terminologia de Todorov, são consideradas como categorias particulares e nomeadas, respectivamente, como o maravilhoso e o estranho. Entretanto, o teórico búlgaro considera que a vasta maioria das obras que estimulam a hesitação no leitor se define como pertencente a um dos gêneros vizinhos em seu desfecho, reservando para uma restrita parcela de textos a designação de fantástico puro. Dessa forma, a incerteza do leitor como característica definidora do gênero representaria, na maior parte dos casos, uma reação efêmera e circunscrita ao momento da leitura. Consequentemente, o fantástico seria mais propriamente uma situação de interação com o texto, limitada pela integração final deste ao maravilhoso ou ao estranho. Não é absolutamente a nossa intenção diminuir a importância da teoria de Todorov e a sua notória influência na produção de trabalhos de indiscutível valor acadêmico. Nossa análise textual se remeterá, inclusive, a alguns de seus preceitos no intuito de demonstrar suas afinidades e contrariedades com a abordagem de Roas. Não obstante, nosso esforço de atualização crítica do texto de Poe recai sobre a sensação de desconforto do leitor resultante da ocupação desse não lugar entre a desafiada realidade e o até então ignorado ou irrefletido desconhecido, aspecto que, a nosso ver, é descrito de forma mais abrangente pelo autor espanhol.

Com efeito, os dois teóricos partem do mesmo ponto para suas respectivas definições do gênero fantástico. Ambos enfatizam a irrupção de um elemento insólito em um universo ficcional que, a princípio, mimetiza

\author{
${ }^{1}$ I will argue that \\ "the moment \\ between" is the key \\ to understanding \\ the nature, the \\ modus operandi, and \\ even the appeal of \\ fantastic narratives. \\ These narratives \\ are exercises in \\ apprehending \\ something beyond \\ language, something \\ unnamable or \\ indescribable that \\ can only emerge \\ when language \\ demonstrates its \\ insufficiencies.
}


a realidade experimental. Comparemos os dois posicionamentos. Todorov afirma que "num mundo que é exatamente o nosso (...) produz-se um acontecimento que não pode ser explicado pelas leis deste mundo familiar” (TODOROV, 1981, p. 30). David Roas, por sua vez, descreve assim o processo de ruptura do mimetismo inicial dos textos do gênero:

O mundo construído nos contos fantásticos é sempre um mundo em que no início tudo é normal e que o leitor identifica com a sua própria realidade [...] Um funcionamento aparentemente normal que, de repente, se verá alterado pela presença do sobrenatural, isto é, por um fenômeno que contradiz as leis físicas que organizam esse mundo. (ROAS, 2014, p. 110).

Não obstante a simetria dos dois discursos sobre essa questão primordial para a caracterização do gênero, as linhas teóricas assumem itinerários distintos no tratamento dos efeitos do fantástico sobre o leitor nas esferas intra e extratextual. O pensador búlgaro distingue de imediato as duas possibilidades de significação da obra e já aponta para os limites genéricos do estranho e do maravilhoso.

Aquele que o percebe deve optar por uma das duas soluções possíveis: ou se trata de uma ilusão dos sentidos, de um produto da imaginação e, nesse caso, as leis do mundo continuam a ser o que são; ou então o acontecimento realmente ocorreu, é parte integrante da realidade, mas nesse caso esta realidade é regida por leis desconhecidas por nós. (TODOROV, 1981, p. 30).

Nesse contexto de recepção, manifesta-se o sentimento de hesitação que é tão importante na perspectiva todoroviana. Como salientamos anteriormente, essa dubiedade raramente trespassa os desfechos das obras, sendo comumente dissipada por explicações lógicas ou pela aceitação do inexplicável.

Em contrapartida, Roas enfatiza o impacto do sobrenatural sobre a dimensão simbólica do processo de leitura, a qual ultrapassa os limites do diálogo com o texto e permite que o fantástico, assim como ocorre na diegese, problematize as certezas do leitor sobre o real.

Baseada, portanto, na confrontação do sobrenatural e do real dentro de um mundo ordenado e estável como pretende ser o nosso, a narrativa fantástica provoca - e, portanto, reflete - a incerteza na percepção da realidade e do próprio eu; a existência do impossível, de uma realidade diferente da nossa, leva-nos por um lado, a duvidar dessa última e causa, por outro, em direta relação com isso, a dúvida sobre a nossa própria existência. (ROAS, 2014, p. 32).

Percebemos, portanto, que o efeito fantástico para o teórico catalão é duplamente referencial. Primeiramente, o leitor reconhece os elementos de sua realidade empírica no espaço ficcional descrito na obra literária. Em segundo lugar, a manifestação do insólito na narrativa leva o receptor não apenas a questionar as regras implícitas no mundo da diegese - representação 
mimética da exterioridade que o circunda -, mas também a refletir sobre os limites de compreensão e racionalização de seu universo experimental.

O fantástico, portanto, depende sempre do que consideramos real, e o real deriva diretamente do que conhecemos. Assim, não podemos manter nossa recepção limitada à realidade intratextual quando nos deparamos com um texto fantástico. (ROAS, 2014, p. 111).

Segundo o ponto de vista de Roas, a determinação do caráter natural ou sobrenatural do evento insólito nas narrativas fantásticas não suprime necessariamente os desdobramentos do processo que, para o autor, distingue o gênero em questão: a desestabilização da noção de real do leitor. "Essa é a razão básica do contato fantástico: revelar algo que vai transtornar nossa concepção da realidade”. (ROAS, 2014, p.114).

Diante desses apontamentos, é necessário fazer duas considerações. Em primeiro lugar, Roas não estende a sua análise para um esforço especulativo sobre o impacto dessa desestabilização no universo empírico do leitor, o qual, é preciso admitir, demandaria um estudo quantitativo e qualitativo extremamente complexo que transcenderia o escopo deste estudo. O autor insiste, no entanto, que o potencial simbólico do fantástico se revela justamente na sua influência sobre o imaginário do leitor, influição que extrapola a efêmera situação de leitura. Além disso, Roas não desmerece os sentimentos de hesitação ou de incerteza como efeitos da narrativa fantástica. Contudo, o teórico não admite que esses sejam os elementos definidores do gênero, mas catalisadores do movimento de desestabilização das noções supostamente íntegras sobre o real. É justamente a partir dessa aproximação da dubiedade do texto fantástico com a problematização do universo empírico do leitor que desenvolveremos nossa análise do conto de Edgar Allan Poe.

Assim como uma parcela considerável dos textos fantásticos, “O gato preto” apresenta um narrador em primeira pessoa que, de forma retrospectiva, expõe os peculiares eventos que teriam marcado a sua história. Esse modelo de foco narrativo não apenas permite o acesso direto do leitor à psique da personagem, mas também o motiva a notar as nuanças do discurso organizado pelo protagonista, especialmente quando se trata da explicação de suas próprias ações. Uma vez que há a expressão de um único ponto de vista na obra, o diálogo com o texto sempre demanda certos cuidados do interlocutor e, em certos casos, como o conto em questão, mesmo uma relativa desconfiança diante do que é narrado. Nesse sentido, o primeiro parágrafo da narrativa de Poe fornece informações relevantes para a análise da personagem e para a caracterização genérica da obra.

Para a narrativa sumamente extravagante e contudo sumamente trivial em que tomo da pena, não espero nem peço crédito. De fato, louco seria eu de esperar tal coisa, num episódio em que até meus próprios sentidos rejeitam o que testemunharam. Contudo, não estou louco - e, decerto, tampouco estou 
sonhando. Mas amanhã morrerei e hoje quero desafogar minha alma. Meu propósito imediato é expor diante do mundo, de modo direto, sucinto e sem comentários, uma série de simples eventos domésticos. ${ }^{2}$ (POE, 2012, p. 64).

As primeiras palavras do trecho citado provocam no leitor um efeito de estranhamento em relação ao objetivo do relato que está prestes a acompanhar. Qual o propósito de tecer toda uma narrativa para a qual não se espera crédito? A nosso ver, essa aparente indiferença do narrador quanto à recepção de sua história denuncia um artifício retórico que busca angariar maior credibilidade da parte de seu interlocutor, i. e., a suposta despreocupação com a natureza crível de suas memórias conduziria o leitor a imaginar que o narrador não teria motivos para omitir ou distorcer quaisquer acontecimentos relatados. Com isso, um aspecto tido como inalienável de todo objeto textual pelos teóricos da recepção ficaria relativamente dissimulado: a sua dimensão argumentativa. Vicent Jouve (2002), por exemplo, afirma que não há texto, especialmente na arte literária, isento de mecanismos retóricos e modelos de representação, os quais interagem diretamente com a consciência e a visão de mundo do leitor. Segundo ele,

O texto como resultado de uma vontade criadora, conjunto organizado de elementos, é sempre analisável, mesmo no caso das narrativas em terceira pessoa, como "discurso", engajamento do leitor perante o mundo e os seres. [...] A intenção de convencer está, de um modo ou de outro, presente em toda narrativa. (JOUVE, 2002, p. 21).

A continuação da primeira sentença agrega ainda mais elementos questionáveis ao discurso do narrador, especialmente se consideramos um ato de releitura do conto. A associação dos termos "extraordinária" e "familiar" produz a impressão de uma caracterização paradoxal dos eventos a serem descritos, que pode ser resolvida pela atribuição de um tom irônico às palavras do protagonista. Tendo o conhecimento de que a narrativa versa sobre o assassinato da esposa da personagem pelas mãos deste e dentro de sua própria residência, o leitor percebe a ambiguidade latente no uso do adjetivo "familiar". O mesmo tipo de apreensão se repete algumas linhas abaixo quando a expressão "meros acontecimentos domésticos” é utilizada.

Além disso, é preciso reconhecer que o narrador apresenta ao leitor não apenas um relato retrospectivo, mas também o faz por meio da escrita. Em primeiro lugar, o distanciamento temporal dos acontecimentos no momento da organização da narrativa permite à personagem refletir cuidadosamente sobre as suas ações e as formas possíveis de caracterizá-las. Segundamente, a produção de um texto sobre o ocorrido potencializa ainda mais a articulação retórica da exposição, tendo em vista as particularidades dessa modalidade específica como, por exemplo, as escolhas de vocabulário, a possibilidade de reescrita e a materialidade visual do discurso.
${ }^{2}$ FOR the most wild, yet most homely narrative which I am about to pen, I neither expect nor solicit belief. Mad indeed would I be to expect it, in a case where my very senses reject their own evidence. Yet, mad am I not -and very surely do I not dream. But to-morrow I die, and to-day I would unburthen my soul. My immediate purpose is to place before the world, plainly, succinctly, and without comment, a series of mere household events. (POE, 1984, p. 63). 
Nas próximas duas sentenças a questão da loucura é colocada no horizonte de análise textual. Inicialmente, o narrador relaciona a perda da sanidade ao próprio fluxo de seu relato e ao seu conteúdo insólito. Em seguida, o protagonista afirma não estar louco e menciona que não está a sonhar. Destacamos essas duas sentenças porque tanto a loucura quanto o sonho ou a alucinação são soluções recorrentes para a presença de elementos sobrenaturais em obras da literatura fantástica. Como afirma Castex, o gênero "permite a expressão daqueles aspectos que se mantêm irredutíveis à razão lógica”3 (CASTEX, 1947, p. 11, tradução nossa).

É justamente essa incompatibilidade com os parâmetros racionais aceitos em um determinado momento de recepção do texto que conduz o leitor para a consideração da insanidade como viés interpretativo. Alicerçado em afirmações menos científicas do que impressionistas, o interlocutor do conto pode reconhecer, inclusive, a negação do narrador como indício de sua loucura. Também com base no senso comum, entretanto, poderíamos questionar se um louco seria capaz de uma estruturação textual e argumentativa tão meticulosa. Se a negação é vista comumente como evidência de uma perturbação mental, a dificuldade e/ou a incapacidade de uma articulação razoável do discurso dentro dos parâmetros aceitos também o são. Salientamos que nossas observações sobre as dinâmicas interpretativas e projetivas na recepção do texto contemplam um leitor que, apesar de modelo, não é versado em estudos da psique humana. Isso não significa, contudo, que o tema da loucura não ocupe uma posição central na análise do conto. Retornaremos a essa questão oportunamente.

Ainda sobre o trecho citado da obra, os parâmetros apontados pelo narrador como norteadores de sua narrativa são perceptivelmente desrespeitados pela personagem ao longo do conto. Ainda que relativamente sucinta, sua exposição não é simples ou desprovida de comentários. Além de um segundo exemplo da tentativa do narrador em afirmar a neutralidade de seu relato, o trecho corresponde também a uma primeira ocorrência de uma série de contradições entre o que ele se propõe a narrar e o que é efetivamente narrado. São justamente as recorrentes tentativas de explicação da personagem que potencializam a essência dúbia de seu testemunho.

A segunda metade do parágrafo inicial do conto apresenta também elementos interessantes sob o ponto de vista das teorias do fantástico.

Por suas consequências, esses eventos me aterrorizaram, me torturaram, me destruíram. Contudo, não farei uma tentativa de explicá-los. Para mim, pouco representaram além do Horror - para muitos, parecerão menos terríveis do que barrocos. Num futuro próximo, talvez, algum intelecto haverá de surgir para reduzir minha fantasmagoria ao lugar-comum - algum intelecto mais calmo, mais lógico e muito menos excitável do que o meu, que perceberá, nas circunstâncias por mim detalhadas com assombro, nada mais do que uma ordinária sucessão de causas e efeitos perfeitamente naturais. ${ }^{4}$ (POE, 2012, p. 64).
${ }^{3}$ Permet d'exprimer ces aspects de l'homme qui demeurent irréductible à la raison logique.

${ }^{4}$ In their consequences, these events have terrified -have tortured -have destroyed me. Yet I will not attempt to expound them. To me, they have presented little but Horror --to many they will seem less terrible than baroques.

Hereafter, perhaps, some intellect may be found which will reduce my phantasm to the common-place -some intellect more calm, more logical, and far less excitable than my own, which will perceive, in the circumstances I detail with awe, nothing more than an ordinary succession of very natural causes and effects. (POE, 1984, p. 63). 
Novamente, o narrador anuncia um comprometimento com a objetividade para o curso do relato que não será cumprida posteriormente. Os constantes esforços da personagem para esclarecer não apenas os eventos insólitos, mas também as circunstâncias de sua progressiva derrocada atribuem ao seu testemunho um tom de encenação, artifício que tenta enredar o leitor nas teias de seus argumentos. Se, para Poe, todos os elementos do conto devem contribuir para o efeito geral do texto, as digressões e as contradições do protagonista não devem ser absolutamente desconsideradas. Ao contrário, elas delineiam a arquitetura espacial e psicológica do texto, na qual o impacto da leitura se concentra. Como salienta Cortázar, nos contos de Poe, mesmo o recurso da procrastinação é uma forma dissimulada de preparar o clímax da narrativa.

No conto vai ocorrer algo, e esse algo será intenso. Todo rodeio é desnecessário sempre que não seja um falso rodeio, ou seja, uma aparente digressão por meio da qual o contista nos agarra desde a primeira frase e nos predispõe para recebermos em cheio o impacto do acontecimento. (CORTÁZAR, 2006, p. 124).

Especificamente em "O gato preto”, o efeito programado pelo texto para o leitor está diretamente associado à manipulação do fantástico na obra. Na parte final do primeiro parágrafo do conto, duas interpretações possíveis da narrativa são identificadas pela própria personagem. Segundo ela, haverá aqueles que compreenderão e compartilharão dos seus sentimentos de perplexidade e de terror. Logo em seguida, o narrador afirma que futuramente poderá surgir uma mente mais lógica que observará os eventos pelo filtro da dinâmica racionalista de causa e efeito. Ao delinear essas duas rotas de leitura, o narrador caracteriza, respectivamente, aquelas que Tzvetan Todorov denomina genericamente de maravilhoso e de estranho, i. e., a aceitação do sobrenatural como elemento do universo ficcional ou a sua neutralização por meio de explicações consideradas plausíveis. Desde um ponto tão inicial da narrativa, em que basicamente nenhum detalhe do enredo foi ainda revelado ao leitor, o mecanismo do fantástico é colocado em funcionamento e o interstício entre formas de significação do texto é criado, espaço de indeterminação que é sustentado ao longo de todo o conto.

Se, para Todorov, essa estrutura é responsável pela hesitação do leitor, que, como vimos, é para ele a característica definidora da literatura fantástica, na visão de Roas, a própria sugestão de uma explicação para os eventos do texto que suplante as noções de real do leitor já serve como elemento determinante do gênero. Uma vez que para o autor catalão a recepção da obra sempre ocorre a partir de associações referenciais com o universo experimental, a insinuação do sobrenatural como parte integrante da diegese faz com o leitor reflita sobre os limites da sua compreensão da realidade em si. 
O fantástico, portanto, está inscrito permanentemente na realidade, a um só tempo apresentando-se como um atentado contra essa mesma realidade que o circunscreve. A verossimilhança não é um simples acessório estilístico, e sim algo que o próprio gênero exige, uma necessidade construtiva necessária para o desenvolvimento satisfatório da narrativa. E não é só isso; toda história fantástica também se apresenta como um acontecimento real para conseguir convencer o leitor da "realidade" análoga do fenômeno sobrenatural. (ROAS, 2014, p. 52).

No conto de Poe, a verossimilhança à qual Roas se refere é profundamente relevante para a dinâmica que se estabelece entre as insinuações sobrenaturais e as explicações racionais que se intercalam no relato do protagonista. Como demonstramos, desde o início da obra, a personagem alude de forma ambígua aos eventos por ele vividos e exibe contradições internas em seu discurso. Tais aspectos, ao invés de comprometerem a sua caracterização, tornam-na ainda mais verossímil ao atribuir ao narrador um nível de complexidade psicológica e linguística que emula os atributos dos indivíduos no universo empírico, mesmo se tratando de um testemunho por escrito. Essa dimensão mimética do narrador contribui não apenas para plausibilidade do espaço ficcional e de seus integrantes, mas também, como veremos, para um dos aparentes objetivos da articulação de todo o relato.

É no interstício entre o puramente verossímil e o desconcertantemente insólito que as diferentes facetas da desestabilização do real tomam forma. Essa indeterminação é sustentada pela ambiguidade inerente à narrativa e engenhosamente tecida por Poe.

No intuito de esclarecer esse mecanismo de indefinição programada de sentido, aludiremos a duas passagens representativas do conto. Primeiramente, consideremos a referência do narrador a um comentário de sua esposa sobre o gato preto.

Falando de sua inteligência, minha esposa, que no fundo não era pouco imbuída de superstição, fazia frequente alusão à antiga crença popular que via em todos os gatos pretos bruxas disfarçadas. Não que em algum momento falasse a sério nesse sentido - e não toco no assunto por nenhum outro motivo além de acontecer, bem agora, de me vir à memória. ${ }^{5}$ (POE, 2012, p. 64).

Neste trecho, o protagonista insinua uma essência mística na existência do gato ao mesmo tempo em que refuta o próprio comentário, tratando-o racionalmente como mero produto da superstição popular. Dessa forma, o sobrenatural e o natural dividem espaço como formas de caracterização do felino, sem que haja, de forma incontestável, a imposição de uma sobre a outra. O que usualmente denominamos de superstição seria apenas um conjunto de fabulações do imaginário coletivo ou a expressão popular de fenômenos inexplicáveis? Essa ambivalência afeta as perspectivas interpretativas da
${ }^{5}$ In speaking of his intelligence, my wife, who at heart was not a little tinctured with superstition, made frequent allusion to the ancient popular notion, which regarded all black cats as witches in disguise. Not that she was ever serious upon this point -- and I mention the matter at all for no better reason than that it happens, just now, to be remembered. (POE, 1984, p. 64) 
obra, tanto em sentido anafórico quanto catafórico. Se a sua menção, por um lado, pode ocasionar um processo de ressignificação simbólica do gato preto desde a primeira referência no título do conto, por outro lado, também pode servir como recurso de predisposição do leitor para os acontecimentos (aparentemente) insólitos descritos na sequência do relato. Não obstante, o ceticismo se mantém como alternativa viável para a recepção do texto, o que restringiria quaisquer representações místicas do gato à esfera da crendice.

Ainda em relação ao excerto citado, é curiosa a intenção da personagem em reduzir, no final da passagem, a importância do que foi dito. O leitor deve se recordar que o testemunho foi feito por meio da escrita, modalidade de expressão que demanda reflexões sobre o seu próprio processo constitutivo, seja no que se refere ao léxico ou à sintaxe, seja em termos de semântica e retórica. Portanto, a escritura de um texto, ao contrário da expressão oral, dificilmente comporta recordações momentâneas e/ou excessos de linguagem, invalidados pelo próprio autor como irrelevantes. Caso assim o fossem, bastaria a ele excluir tais trechos de seu relato.

O segundo exemplo a ser destacado é o incêndio na casa do narrador, que acontece exatamente na noite do assassinato do gato. Nesse mesmo episódio, causa estranheza a enorme imagem de um gato que surge gravada em uma das paredes da casa após o desastre. Ambas as ocorrências inspiram explicações sobrenaturais, sendo uma delas a vingança sobrenatural de Pluto, morto pelo protagonista algumas horas antes. Todavia, a própria personagem apresenta uma análise plausível, ainda que improvável, para o aparecimento da figura estampada no reboco.

A imagem se estampava com uma precisão realmente maravilhosa. Havia uma corda em torno do pescoço do animal. Quando contemplei a aparição - pois como menos que isso eu dificilmente podia encará-la - minha admiração e meu terror foram extremos. Até que enfim a reflexão veio em meu auxílio. O gato, lembrei, fora enforcado em um jardim adjacente à casa. Ao alarme de incêndio, esse jardim fora imediatamente tomado pela multidão - e alguém ali devia ter cortado a forca e jogado o animal por uma janela aberta dentro do meu quarto. Isso provavelmente fora feito com o intuito de me despertar de meu sono. A queda de outras paredes comprimira a vítima de minha crueldade na massa da alvenaria recém-aplicada; a cal do reboco, sob a ação do fogo, combinara-se ao amoníaco da carcaça para executar o esboço tal como eu o via. ${ }^{6}$ (POE, 2012, p. 66-67).

Essa dinâmica de proposições contraditórias para a descrição dos fenômenos é complementada por aspectos do texto que, ainda que de forma menos explícita, reforçam o caráter ambíguo do relato. Dentre eles, ressaltamos novamente uma característica inerente ao foco narrativo em primeira pessoa: a unicidade de ponto de vista. Assim, a mancha em forma de cadafalso no peito do segundo gato, por exemplo, pode ser entendida como
${ }^{6}$ The impression was given with an accuracy truly marvellous. There was a rope about the animal's neck. When I first beheld this apparition -- for I could scarcely regard it as less - my wonder and my terror were extreme. But at length reflection came to my aid. The cat, I remembered, had been hung in a garden adjacent to the house. Upon the alarm of fire, this garden had been immediately filled by the crowd --by some one of whom the animal must have been cut from the tree and thrown, through an open window, into my chamber. This had probably been done with the view of arousing me from sleep. The falling of other walls had compressed the victim of my cruelty into the substance of the freshly-spread plaster; the lime of which, had then with the flames, and the ammonia from the carcass, accomplished the portraiture as I saw it. (POE, 1984, p. 66). 
uma projeção subjetiva, já que não há a confirmação de outras personagens dessa estranha coincidência.

Ainda que a obra de David Roas constitua nosso principal aporte teórico, recorreremos uma vez mais ao pensamento de Tzvetan Todorov no intuito de refletir sobre uma característica do conto de Poe que, segundo a teoria da hesitação do teórico búlgaro, seria incomum. Como vimos, Todorov argumenta que as incertezas do texto fantástico e a consequente hesitação do leitor tendem a ser resolvidas no desfecho da vasta maioria das obras do gênero. Entretanto, o autor também afirma que há casos nos quais a ambiguidade jamais é solucionada, fazendo com que a vacilação do receptor jamais seja direcionada para uma explicação definitiva. "Seria errôneo pretender que o fantástico só pode existir em uma parte da obra. Há textos que conservam a ambiguidade até o final, quer dizer, além desse final. Uma vez fechado o livro, a ambiguidade subsiste”. (TODOROV, 1981, p. 49).

Nessas eventualidades, o texto se mantém como interstício permanente entre dois modos de concretização da narrativa. Assim como o conto “A história do falecido Sr. Elveshaw” (1896), de H. G. Wells, e a novela A volta do parafuso (1898), de Henry James, “O gato preto” se enquadra nessa categoria da literatura fantástica.

Se refletirmos sobre essa particularidade da narrativa de Poe a partir dos pressupostos de Roas, percebemos que o processo de desestabilização do real, assim como a sua implicação na dimensão simbólica da leitura, torna-se multifacetado em escala proporcional ao número de possibilidades de significação do texto. "A indeterminação se converte em um artifício para colocar em marcha a imaginação do leitor”. (ROAS, 2014, p. 58).

Primeiramente, discorreremos sobre a perspectiva de leitura que admite a ocorrência de eventos sobrenaturais e, portanto, racionalmente inexplicáveis no conto. Como vimos, o narrador sugere, desde o início do relato, o caráter extraordinário de seu relato. Essa sugestão não é apenas mantida, mas intensificada ao longo do texto por meio de diferentes recursos retóricos e lexicais, dentre os quais destacamos o uso recorrente de termos da esfera do misticismo religioso como, por exemplo, demônio e possessão. Além dessa terminologia, é preciso considerar a ambiguidade inerente a certas descrições episódicas, que permitem a inferência da ação de forças sobrenaturais, como nos dois exemplos citados previamente.

De acordo com essa linha de análise, o protagonista teria sido punido pelos seus atos de brutalidade contra Pluto e, posteriormente, contra sua esposa, os quais poderiam ser entendidos, inclusive, como resultantes de influências demoníacas. Nessa visão, o segundo gato seria a reencarnação do animal enforcado, cuja presença impele o protagonista para o assassinato e, no desfecho do conto, aparece no esconderijo do cadáver para denunciar o narrador. Com isso, a sentença final do conto - "Eu emparedara o monstro dentro da tumba!”7 (POE, 2012, p. 71) - assume uma conotação ainda mais peculiar.

${ }^{7}$ I had walled the monster up within the tomb! (POE, 1984, p. 70). 
Seguindo os postulados de David Roas, o reconhecimento do sobrenatural na obra faria com que o leitor refletisse sobre a possibilidade de que forças místicas manipulassem indivíduos (e mesmo animais) no mundo empírico, o que obviamente questionaria um entendimento positivista das leis que gerem esse universo.

É preciso considerar que o termo manipulação seria o mais correto a ser utilizado na leitura sob o prisma do sobrenatural, já que as atitudes do protagonista são sempre admitidas por ele como derivadas de sua própria vontade. Nesse sentido, os agentes sobrenaturais apenas tentariam o sujeito, mas a efetivação das ações é sempre mediada pelo livre arbítrio. Mesmo quando descreve a si mesmo por meio de associações metafísicas, o narrador reconhece uma maldade inerente ao ser humano, que, segundo ele, seria um traço herdado do próprio Criador.

E agora eu estava de fato desgraçado para além da desgraça da mera Humanidade. E uma criatura bruta - cujo semelhante eu matara desprezivelmente - uma criatura bruta engendrara para mim - para mim, um homem, feito à imagem do Deus Altíssimo - tamanho e insuportável suplício! $^{8}$ (POE, 2012, p. 67-68).

Ao mesmo tempo em que o trecho acima parece corresponder a uma mistificação da maldade humana, o conhecimento que o leitor tem dos recursos discursivos do narrador influencia na incredulidade quanto aos argumentos apresentados. A ambiguidade que se revela na passagem nos leva para uma segunda interpretação possível do conto: a responsabilização do narrador pelos seus próprios infortúnios e tormentos.

Para Todorov, essa hipótese guia o leitor para dentro dos limites do estranho e privilegia a análise psicológica da personagem. David Roas, por sua vez, concentra o seu foco teórico sobre os textos que claramente representam fenômenos sobrenaturais em seus enredos. Todavia, o autor afirma que seus postulados podem ser aplicados em obras que, como "O gato preto”, mantém o seu caráter ambíguo para além de seus desfechos. “Minha definição inclui tanto as narrativas em que a evidência do fantástico não está sujeita a discussão, quanto aquelas em que a ambiguidade é insolúvel, já que todas postulam a mesma ideia: a irrupção do sobrenatural no mundo real” (ROAS, 2014, p. 43).

É precisamente essa abertura teórica que exploraremos a partir deste momento, tendo como objetivo demonstrar que a análise mimético-realista mantém o processo de desestabilização do leitor e, a nosso ver, duplica-a em dois pontos de vista. Para esclarecer esse efeito, trataremos de algumas facetas das manifestações da psique do protagonista no conto.

Após o parágrafo inicial, o narrador expõe momentos significativos do seu desenvolvimento pessoal, incluindo suas dificuldades de socialização e a sua progressiva aproximação das mais diferentes espécies de animais

\footnotetext{
${ }^{8}$ And now was I indeed wretched beyond the wretchedness of mere Humanity. And a brute beast -whose fellow I had contemptuously destroyed -a brute beast to work out for me - for me a man, fashioned in the image of the High God -so much of insufferable wo! (POE, 1984, p. 67).
} 
em substituição ao contato humano, o qual é entendido pela personagem como volúvel e insidioso. "Há qualquer coisa no amor altruísta e abnegado de uma criatura bruta que cala fundo no coração de quem muitas vezes já teve ocasião de experimentar a amizade mesquinha e a fidelidade impalpável do mero Homem". ${ }^{9}$ (POE, 2012, p. 64).

A descrição desse processo de transferência, assim como a menção de experiências traumáticas vividas na infância, inscreve definitivamente no horizonte de significação do leitor a possibilidade de análise psicológica das palavras e das ações do protagonista. A personagem assume então uma dimensão mimética bem delineada que favorece a identificação do receptor, i.e., o texto representa um indivíduo que, assim como diversos outros seres humanos, passou por momentos de dor e de ressentimento em sua formação pessoal, os quais podem ter moldado aspectos de sua personalidade e de seu comportamento.

A carência afetiva do narrador, por exemplo, conflui tão diretamente para a sua relação com os animais que os comentários sobre a sua esposa e as circunstâncias de seu casamento, além de muito breves, enfatizam unicamente a afeição compartilhada pelos bichos de estimação. "Casei cedo e tive a felicidade de encontrar em minha esposa uma disposição não incompatível com a minha. Percebendo a minha preferência pelos animais domésticos, ela não perdia a oportunidade de obter os tipos mais agradáveis" ${ }^{10}$ (POE, 2012, p. 64). Nesse sentido, é interessante notar que a descrição do gato Pluto ocupa um espaço muito mais amplo na narrativa do que quaisquer referências à cônjuge do protagonista. Essa desproporcionalidade pode indicar ao leitor que experiências pregressas criaram na personagem uma atávica desvalorização dos seres humanos, o que, por sua vez, pode lançar luz sobre a sua frieza no momento do assassinato e da ocultação do cadáver da esposa.

Contudo, o comportamento do narrador descreve uma longa curva de deterioração no conto até a consumação do crime capital. Segundo ele, a explicação para a mudança de seu caráter foi uma crescente e incontrolável impaciência, que se tornara ainda mais desmedida com o uso frequente do álcool.

Pluto - esse o nome do gato - foi meu bicho e companheiro favorito [...] Nossa amizade durou, desse modo, por vários anos, durante os quais meu temperamento geral e caráter - por obra do Demônio da Intemperança - experimentaram (coro em confessar) uma radical alteração para pior. Torneime, a cada dia, mais taciturno, mais irritável, mais sem consideração pelos sentimentos alheios. Permitia-me o uso de uma linguagem destemperada com minha mulher. Por fim, cheguei até a ameaçá-la de violência física. Meus bichos, é claro, também sofreram com minha mudança de disposição. Eu não só os negligenciava, como também os maltratava. ${ }^{11}$ (POE, 2012, p. 65, grifo nosso).

Os rompantes violentos do narrador atingem finalmente aquele que ainda se mantinha relativamente protegido da sua intempestividade: o gato
${ }^{9}$ There is something in the unselfish and self-sacrificing love of a brute, which goes directly to the heart of him who has had frequent occasion to test the paltry friendship and gossamer fidelity of mere Man. (POE, 1984, p. 63-64).

${ }^{10}$ I married early, and was happy to find in my wife a disposition not uncongenial with my own. Observing my partiality for domestic pets, she lost no opportunity of procuring those of the most agreeable kind. (POE, 1984, p. 64)

${ }^{11}$ Pluto - this was the cat's name - was my favorite pet and playmate [...] Our friendship lasted, in this manner, for several years, during which my general temperament and character - through the instrumentality of the Fiend Intemperance - had (I blush to confess it) experienced a radical alteration for the worse. I grew, day by day, more moody, more irritable, more regardless of the feelings of others. I suffered myself to use intemperate language to my At length, I even offered her personal violence. My pets, of course, were made to feel the change in my disposition. I not only neglected, but ill-used them. (POE, 1984, p. 64 , grifo nosso) 
preto. Considerando a predileção do protagonista por animais em detrimento a seres humanos, a preservação da integridade do gato (mesmo depois das agressões à esposa) é coerente com a representação da sua psique no conto. De certa forma, a personagem rompe progressivamente os limites de ética e civilidade até o momento em que o carinho por Pluto se torna o último resquício daquela sensibilidade infantil. É importante perceber, no entanto, que o primeiro ato de grande brutalidade contra o animal ocorre justamente porque o narrador sente que o felino o evita e, uma vez acuado, fere a sua mão. A personagem se sente traída e desprezada pela única criatura com a qual ainda se importava.

Certa noite, voltando para casa, muito embriagado, de uma das minhas aventuras pela cidade, julguei que o gato evitava a minha presença. Apanhei-o, e ele, horrorizado com a violência do meu gesto, infligiu-me um leve ferimento na mão com os dentes. [...] Tirei do bolso do colete um pequeno canivete, abri-o, agarrei o pobre animal pela garganta e deliberadamente arranquei um de seus olhos da órbita! Coro, enrubesço, estremeço conforme descrevo a abominável atrocidade. ${ }^{12}$ (POE, 2012, p. 65, grifo nosso).

Além do exposto, há em ambos os trechos citados o uso de expressões (em negrito) que apontam para sentimentos como vergonha e culpa. Entretanto, o plano de expressão da narrativa é profundamente revelador das contradições que habitam na personagem. Ainda que a princípio o leitor possa acreditar nas reações do narrador, evidencia-se já no próximo parágrafo que a passagem do tempo dilui rapidamente esses impulsos de arrependimento e reconduz o protagonista ao seu comportamento agressivo.

Eu experimentei um sentimento que era parte horror, parte remorso pelo crime do qual eu era culpado; mas foi quando muito, um sentimento fraco e ambíguo, e a alma permaneceu intocada. Voltei a mergulhar em excessos e não tardei a afogar na bebida qualquer lembrança do ato. ${ }^{13}$ (POE, 2012, p. 65).

Ainda que mantenhamos o foco restrito a uma análise mimética do conto, essas incongruências no fluxo do relato colocam o leitor diante de duas possibilidades de caracterização da personagem, o que intensifica ainda mais o signo da ambiguidade na obra. Redunda justamente dessa ambivalência a ampliação do processo de desestabilização do real em “O gato preto”.

Primeiramente, poderia ser atribuída ao protagonista uma condição patológica que explicaria, em grande medida, as suas ações. Recuperando um argumento já mencionado, a negação da loucura no primeiro parágrafo do conto indicaria, segundo percepções arraigadas no imaginário coletivo, um sintoma da própria insanidade.

Com a consideração de algum tipo de distúrbio, outros aspectos do relato assumem também novos sentidos como, por exemplo, a inexatidão nas descrições de determinadas situações, a dificuldade em distinguir realidade
${ }^{12}$ One night, returning home, much intoxicated, from one of my haunts about town, I fancied that the cat avoided my presence. I seized him; when, in his fright at my violence, he inflicted a slight wound upon my hand with his teeth. [...] I took from my waistcoat-pocket a pen-knife, opened it, grasped the poor beast by the throat, and deliberately cut one of its eyes from the socket! I blush, I burn, I shudder, while I pen the damnable atrocity. (POE, 1984, p. 64, grifo nosso)

${ }^{13}$ I experienced a sentiment half of horror, half of remorse, for the crime of which I had been guilty; but it was, at best, a feeble and equivocal feeling, and the soul remained untouched. I again plunged into excess, and soon drowned in wine all memory of the deed. (POE, 1984, p. 64) 
(intradiegética, obviamente) de alucinações e as atitudes extremamente violentas que se seguem. Seria possível, inclusive, associar o vocabulário místico do narrador a devaneios resultantes dessa perturbação psicológica. “A fúria de um demônio apossou-se instantaneamente de mim. Eu não mais me reconhecia. Minha alma original pareceu, na mesma hora, levantar voo de meu corpo; e uma malevolência mais do que diabólica, inflamada a gim, convulsionou cada fibra de meu corpo". ${ }^{14}$ (POE, 2012, p. 65).

Essa interpretação do testemunho e dos eventos nele contidos sugere para o receptor que o universo experimental é um espaço repleto de perigos que podem nunca ter sido plenamente considerados, como a existência de pessoas que, influenciadas por certas patologias, podem cometer atos de grande violência. Neste ponto, ressaltamos que não há premeditação no assassinato da esposa, o que poderia indicar, dentre outras explicações, um surto psicótico no protagonista.

Mesmo sem se afastar de um olhar mimético-realista, notamos, portanto, que o leitor encontra elementos potencialmente desestabilizadores de um senso de realidade centrado no racionalismo e na coerência das ações. A mente humana, espaço ainda resistente a exegeses definitivas, permanece como fonte de terrores e fantasmagorias, que fomentam a literatura fantástica antes e depois das teorias psicanalíticas freudianas.

Contudo, devemos considerar que um segundo procedimento de interpretação do texto pelo viés realista pode trazer conclusões ainda mais desconcertantes para o leitor. A atribuição da condição de louco para um criminoso ou, mais especificamente, para um assassino pode servir como recurso discursivo e simbólico para manter certa ordem ao mundo das relações. Por meio dessa racionalização, estabelece-se uma exceção patológica ao grande conjunto dos comportamentos e dos perfis identitários humanos. Em outros termos, a caracterização de um assassínio como uma anomalia ético-moral perpetrada por uma psique doente resguarda a idealização de uma sociedade funcional e ética. Ainda que permeável a casos de exceção, o mundo, ao menos nesse aspecto, pode continuar em seu eixo.

Mas, e se essa concepção da realidade não ultrapassar os limites de um discurso utópico pacificador? E se as patologias ou mesmo as condições econômicas não forem os únicos motivadores das atrocidades? E se o assassino não for psicologicamente doente?

Em "O gato preto", essa hipótese encontra diferentes pontos de ancoragem. Primeiramente, consideremos a habilidade retórica do narrador, o qual demonstra ter um controle bastante razoável sobre o seu relato, utilizando, inclusive, estratégias para angariar a credibilidade de seu leitor. Além disso, os pequenos toques de ironia no testemunho indicam tanto a consciência de seus atos quanto o desprezo pela seriedade de suas consequências. Citamos anteriormente o uso do vocábulo doméstico no primeiro parágrafo da narrativa e agora complementamos essa linha de raciocínio com outra passagem
${ }^{14}$ The fury of a demon instantly possessed me. I knew myself no longer. My original soul seemed, at once, to take its flight from my body; and a more than fiendish malevolence, gin-nurtured, thrilled every fibre of my frame. (POE, 1984, p. 64). 
emblemática do conto: “[...] e nisso, no pleno frenesi de minha bravata, bati fortemente, com a bengala que levava na mão, exatamente naquela parte da alvenaria atrás da qual jazia o cadáver de minha amantíssima esposa”15 (POE, 2012, p. 71, grifo nosso).

Mesmo quando a tendência irônica não é notável, há uma aparente falta de arrependimento da parte do protagonista, seja pela mutilação e extermínio do gato, seja pela execução de sua companheira. As manifestações de consternação às quais nos referimos anteriormente - claramente efêmeras e tipicamente exageradas - são eclipsadas pela objetividade na ocultação do cadáver e pelo entusiasmo do narrador ao ver sua mórbida tarefa realizada.

Tendo buscado argamassa, areia e crina, com todas as precauções possíveis, preparei um reboco que fosse indistinguível do antigo, e com ele procedi muito diligentemente à obra da nova alvenaria. Após terminar, observei satisfeito o trabalho bem feito. A parede não apresentava o menor sinal de ter sido perturbada. Recolhi o entulho no chão com cuidado mais do que minucioso. Olhei em torno em triunfo e disse comigo mesmo - "Aí está, pronto, meu trabalho não foi em vão"16. (POE, 2012, p. 70) ${ }^{17}$

Finalmente, devemos considerar a preleção do narrador sobre o espírito da perversidade, na qual ele afirma abertamente que não é diferente de qualquer outro ser humano, uma vez que todos nós, devido a uma maldade inata e inalienável, seríamos capazes de atos semelhantes. Ainda que neste ponto da obra o assassinato da esposa não tenha ocorrido, entendemos que a argumentação é válida para o todo relato, uma vez que os eventos são narrados retrospectivamente.

E então sobreveio, como que para minha ruína final e irrevogável, o espírito da PERVERSIDADE. Desse espírito a filosofia não se ocupa. Contudo, não tenho tanta convicção sobre a existência de minha alma quanto tenho de que a perversidade é um dos impulsos primitivos do coração humano - uma das indivisíveis e primordiais faculdades, ou sentimentos, que orientam o caráter do Homem. Quem nunca se pegou, uma centena de vezes, cometendo algum ato vil ou tolo sem nenhum outro motivo além de saber que não deveria? Não mostramos uma perpétua inclinação, malgrado todo o nosso bom-senso, a violar essa coisa que chamamos Lei, meramente porque a compreendemos como tal ${ }^{18}$ (POE, 2012, p. 65-66).

Ao estabelecer uma relação direta entre suas atitudes e uma característica supostamente ingênita da humanidade, o narrador não apenas recusa novamente a qualificação de louco, mas também objetiva promover e/ou fortalecer a identificação do leitor consigo. A nosso ver, essa busca por reconhecimento e compreensão é o verdadeiro propósito de todo o seu testemunho. Sua intenção é criar um espelho em que o receptor veria sua imagem refletida nas ações brutais cometidas, as quais, destituídas, nessa perspectiva, de explicações patológicas, revelar-se-iam essencialmente
15 [...] and here, through the mere phrenzy of bravado, I rapped heavily, with a cane which I held in my hand, upon that very portion of the brick-work behind which stood the corpse of the wife of my bosom. (POE, 1984, p. 69, grifo nosso)

${ }^{16}$ Having procured mortar, sand, and hair, with every possible precaution, I prepared a plaster which could not be distinguished from the old, and with this I very carefully went over the new brick-work. When I had finished, I felt satisfied that all was right. The wall did not present the slightest appearance of having been disturbed. The rubbish on the floor was picked up with the minutest care. I looked around triumphantly, and said to myself -_'Here at least, then, my labor has not been in vain.” (POE, 1984, p. 68-69).

${ }^{17}$ Respeitosamente discordamos da tradução apresentada na obra referenciada da última sentença da passagem. Neste trecho, confunde-se, aparentemente, a expressão "at least" (pelo menos) com “at last” (finalmente).

Considerando essa diferença semântica, acreditamos que a versão: "Pelo menos aqui, o meu trabalho não foi em vão!”

(POE, 2003, p. 48) enfatiza não apenas 
humanas. O narrador não deseja aliviar a sua alma por meio da confissão, mas marcar a sua existência através da naturalização de seus atos. O postulado resultante dessa argumentação seria o de que qualquer indivíduo, plenamente consciente de suas decisões e considerado mentalmente sadio, poderia agir do mesmo modo que o protagonista do conto.

Manifesta-se, diante disso, a segunda desestabilização do real sob um ponto de vista analítico de ordem mimético-realista. O leitor é confrontado por uma concepção da natureza humana que problematiza o entendimento do mundo ao seu redor. Se a patologização do crime permite a manutenção de certa ordem no universo empírico, a sua naturalização ameaça os limites da própria noção da humanidade como uma espécie social. Nesse processo, há novamente um caráter dual. Por um lado, o receptor pode reexaminar o seu juízo sobre a violência cotidiana e sobre os riscos potenciais da vida em coletividade. Por outro lado, ele pode questionar as suas próprias tendências agressivas e encontrar, em maior ou menor grau, alguma concordância com as ideias do narrador sobre si e sobre a raça humana. Para David Roas, o efeito de desestabilização da literatura fantástica não atinge apenas a visão do sujeito sobre o espaço extradiegético, mas também (e, às vezes, de forma mais contundente) a percepção de si mesmo como integrante desse locus. Um dos perigos do encontro com “monstros” é que ele pode desvelar os traços de monstruosidade que temos em comum. Como salientou Louis Vax "é através de mim que o monstro existe. A transcendência fantástica reside no coração dessa imanência”. ${ }^{19}$ (VAX, 1965, p. 311, tradução nossa).

Neste artigo, objetivamos demonstrar que o conto de Edgar Allan Poe, além de ser um texto exemplar de diferentes mecanismos marcantes da literatura fantástica, amplia significantemente as potencialidades do gênero no que se refere aos seus efeitos na dimensão simbólica da leitura. Isso se dá pela operacionalização cuidadosa de um dos elementos mais relevantes do fantástico: a ambiguidade. Ao sugerir diferentes formas de significação da narrativa, sem impor ou invalidar nenhuma delas, o autor cria um espaço intersticial que, ao romper com dualismo típico dos processos de representação e da própria linguagem, obriga o leitor a lidar com a multiplicidade de sentidos e com a incerteza das escolhas. Essa circunstância de recepção potencializa a sensação de desestabilização do real, que, em “O gato preto”, não se restringe à insinuação do sobrenatural e permeia as interpretações que, guiadas por perspectivas realistas de análise, são questionadas em suas próprias concepções do real. Assim como na representação da Máscara da Eternidade, a transcendência imanente e diacrônica do conto de Poe continua a desafiar os mais diversos binarismos.

\section{Referências}

CASTEX, Pierre. Anthologie du Conte Fantastique Français. Paris: Libraire José Corti, 1947. o entusiasmo da personagem com a ação realizada, mas também o ineditismo de um ato tão bem desempenhado na vida do protagonista, o que torna ainda mais complexa a análise de sua psique e dos limites do sobrenatural.

${ }^{18}$ And then came, as if to my final and irrevocable overthrow, the spirit of PERVERSENESS. Of this spirit philosophy takes no account. Yet I am not more sure that my soul lives, than I am that perverseness is one of the primitive impulses of the human heart --one of the indivisible primary faculties, or sentiments, which give direction to the character of Man.

Who has not, a hundred times, found himself committing a vile or a silly action, for no other reason than because he knows he should not? Have we not a perpetual inclination, in the teeth of our best judgment, to violate that which is Law, merely because we understand it to be such? (POE, 1984, p. 65).

${ }^{19} \mathrm{C}$ 'est par moi que le monstre existe. La 'transcendance' fantastique habite au coeur d'une immanence. 
CORTÁZAR, Julio. Valise de cronópio. Tradução de Davi Arriguei Jr. e João Alexandre Barbosa. São Paulo: Perspectiva, 2006.

JOUVE, Vincent. A leitura. Tradução de Brigitte Hervor. São Paulo: Editora UNESP, 2002.

JAUSS, H. R. A história da literatura como provocação à teoria literária. Tradução de Sérgio Tellaroli. São Paulo: Ática, 1994.

PIKE, Karen. Theories of the Fantastic: Postmodernism, Game Theory and Modern Physics. 2010. Tese (Doutorado) - Centre for Comparative Literature, University of Toronto, Toronto.

POE, Edgar A. Complete Stories and Poems of Edgar Allan Poe. New York: Doubleday, 1984.

. Contos de Imaginação e Mistério. Tradução de Cássio de Arantes Leite. São Paulo: Tordesilhas, 2012.

Histórias extraordinárias. Tradução de Brenno Silveira et al. São Paulo: Abril Cultural, 2003.

ROAS, David. A ameaça do fantástico: aproximações teóricas. Tradução de Julián Fuks. São Paulo: Editora UNESP, 2014.

TODOROV, Tzvetan. Introdução à literatura fantástica. Tradução de Silvia Delpy. São Paulo: Perspectiva, 1981.

VAX, Louis. La séduction de l’étrange: étude sur la littérature fantastique. Paris: Presses Universitaires de France, 1965.

Recebido em agosto/2018.

Aceito em outubro/2018. 